\title{
Georges Benko emlékére
}

\section{In memory of Georges Benko}

\section{BARTA GYÖRGYI}

Megismerkedésünk 1987-88-ra tehető, amikor Georges Benko Budapesten járt, illetve meglátogattam a Sorbonne-on, ahol tanár volt. Attól kezdve folyamatosan küldte az akkor Magyarországon többnyire elérhetetlen szakirodalom könyveit, cikkeit, másolt példányait, amivel - egy kutató csak tudja! - hihetetlenül nagy segítséget nyújtott.

1991-ben felajánlotta fordításra az akkor még meg nem jelent könyvének - Géographie des technopôles - kéziratát, megszerezte a kiadó engedélyét, hogy némileg csökkentett terjedelemben magyarul is megjelenhessen a könyv. Az MTA Regionális Kutatások Központjában kollégáimmal lefordítottuk, én szerkesztettem a kéziratot a magyar nyelvű kiadás számára. Hosszabb francia ösztöndíjam alatt, 1992 elején, Georges-zsal fejezetről fejezetre hasonlítottuk, javítottuk a fordítást, majd a Soros Alapítvány pályázatán nyert pénzen az MTA Regionális Kutatások Központja megjelentette „Technológiai parkok és technopoliszok földrajza” címmel. A könyv első része az 1970-es évek gazdasági válságával, ipari átalakulásával, valamint az innovációval és a K+F-tevékenységgel, a technológiai fejlődés pályájával, az újonnan formálódó ipari terekkel foglalkozott. A második részben a Szilícium-völgyet és a többi híressé vált amerikai technológiai parkot mutatta be, valamint az állami gazdaság- és iparpolitika fontos eszközeit, a másoknak is mintául szolgáló japán, angol és főleg a francia technológiaipark-fejlesztéseket. Mennyire aktuális ma is Georges Benko könyve! A magyar területfejlesztésben e könyv ismeretei is hozzájárultak az 1990-es évek derekán az iparipark-építés országos programjának megalapozásához, majd 10 évvel később, a növekedésipólus-elméleten alapuló új fejlesztéshez: az úgynevezett pólusprogram megfogalmazásához és bevezetéséhez (közvetlen francia kormányzati tanácsadással). Ez az utóbbi program - francia mintára - a régióközpontok fejlesztését tűzte ki célul az élenjáró iparvállalatok, a helyi egyetemek és kutatóintézetek K+F-tevékenységének és az állami irányításnak, támogatásnak összefogásával.

Magyar nyelvre még egy könyvét fordították le: a „Regionális tudomány” címüt, amely először 1998-ban jelent meg „La science régionale” címen a

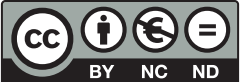


Presses Universitaires de France kiadásában. A társadalomtudományok egyik legújabb ágazata a regionális tudomány, amely Georges Benko szavaival „azt vizsgálja, hogy milyen módon alakítja az ember a teret" (Benko 1999, 15). A regionális tudomány a közgazdaságtan, a földrajz, a történettudomány, a szociológia, a politika- és jogtudomány, az urbanisztika, az antropológia határtudománya, interdiszciplináris megközelítés. Ebben a könyvben Georges Benko arra törekedett, hogy leírja a regionális tudomány helyét a társadalomtudományok körében, illetve hogy bemutassa e tudomány belső logikáját. A „magyar szakma" igen gyors volt, ez a fontos alapkönyv nálunk egy évvel később már meg is jelent. Nem véletlenül... Az 1980-as, 90-es évekhez köthető a regionális tudomány önálló diszciplínává alakulása Magyarországon. A könyv megszületésében bábáskodott Enyedi György és Horváth Gyula, akik maguk is a magyar regionális tudománnyal foglalkozó kutatóintézmények, folyóirat megalapítói közé tartoznak. Georges Benko könyve pedig mind a mai napig aktuális, hiszen a regionális tudomány körüli és azon belüli viták nem csitultak (a Tér és Társadalom legutóbbi számában Lengyel Imre cikke a regionális tudomány megkérdőjelezett térnyeréséről polemizál).

1997-ben jelent meg a Tér és Társadalomban magyar fordításban (fordította Barta Gy. és Králik M.) Benko írása „A regionális fejlődés útjai: globálistól a lokálisig" címmel. Ez a cikk a híressé vált könyv (Les Régions qui Gagnent, 1992) legfontosabb állításait, mondanivalóját süríti egy tanulmányba. Arról a vitáról szól, amely a régiók sikerességét magyarázva szembeállítja a nemzetközi munkamegosztás hatását az endogén fejlődéssel. A globális-lokális vita ma is élénk Magyarországon, és nálunk is hatott, hat a területfejlesztés elméleti megalapozására.

Georges Benko fontos szerepet töltött be a regionális tudomány elméleti gondolkodói között. Sajnos nem foglalkozott az 1990-es évek eleji keleteurópai átalakulással, és szakmai érdeklődéséből Magyarország is kimaradt. Viszont olyan friss szemléletű és főleg elméleti jellegű tudással rendelkezett, ami nem volt erőssége akkoriban a „magyar regionális szakmának”, és ami égetően hiányzott az új, modern tudományág elméleti megalapozásához Magyarországon. Már az említett három könyv, illetve tanulmány is jelentős hatást gyakorolt a regionális tudománnyal foglalkozó magyar szellemi életre.

Kollégáimmal szerettük volna Georges Benkot még jobban bekapcsolni a magyar tudományos életbe. Enyedi professzor meghívta - a Professzorok Háza vendégül látta - az 1990-es évek közepén rövid időre... Sajnos, csak ennyire tellett akkor. Később elvállalta - ajánlásomra - az European Spatial Research and Policy folyóirat felkérésére a szerkesztőbizottsági tagságot. Több évig tartó gyötrelmes betegsége és korai halála nagyon szűkre szabta számunkra az együttműködést. Georges Benko mindvégig segítőkész, jó barát maradt, feleségével, a szociológus Judith Lázárral együtt. 


\section{Irodalom}

Benko, G. (1997): Ways of Regional Development: from Globality to Locality. A regionális fejlődés útjai: globálistól a lokálisig. Tér és Társadalom, 2.1-16. (Fordította Barta, Gy., Králik M.)

Benko, G., Lipietz, A. (eds.) (1992): Les régions qui Gagnent. Presses Universitaires de France, Paris

Benko, G. (1991): Géographie des technopoles. Masson, Paris

Benko, G. (1992): Technológiai parkok és technopoliszok földrajza. MTA Regionális Kutatások Központja, Budapest (Fordította és szerkesztette Barta Gy. et al.)

Benko, G. (1998): La science régionale. Presses Universitaires de France, Paris

Benko, G. (1999): Regionális tudomány. Dialóg Campus Kiadó, Pécs-Budapest. (Fordította Csizmadia D., Enyedi Gy.)

Lengyel I. (2010): A regionális tudomány „térnyerése”. Tér és Társadalom, 3. 11-41. 